\title{
Will Agroforests Vanish? The Case of Damar Agroforests in Indonesia
}

\author{
Koen Kusters • Manuel Ruiz Pérez • Hubert de Foresta • \\ Ton Dietz • Mirjam Ros-Tonen • Brian Belcher • \\ Philip Manalu • Ani Nawir • Eva Wollenberg
}

Published online: 4 June 2008

(C) The Author(s) 2008

\begin{abstract}
Resin producing agroforestry in the Krui area of Sumatra in Indonesia is presented as an environmentally friendly, income generating land-use system which contributes to both development and conservation objectives. We studied the change in household income portfolios in three communities in the Krui area. The studies revealed that in the period 1995-2004 agroforestry remained the main source of income. We predict, however, that due to declining resin productivity per hectare, and rising price and demand for timber, an increasing number of farmers will cut their mature agroforests in the near future. At the same time our data suggests that farmers will continue tree planting activities. In result old agroforests may vanish while new ones will be established.
\end{abstract}

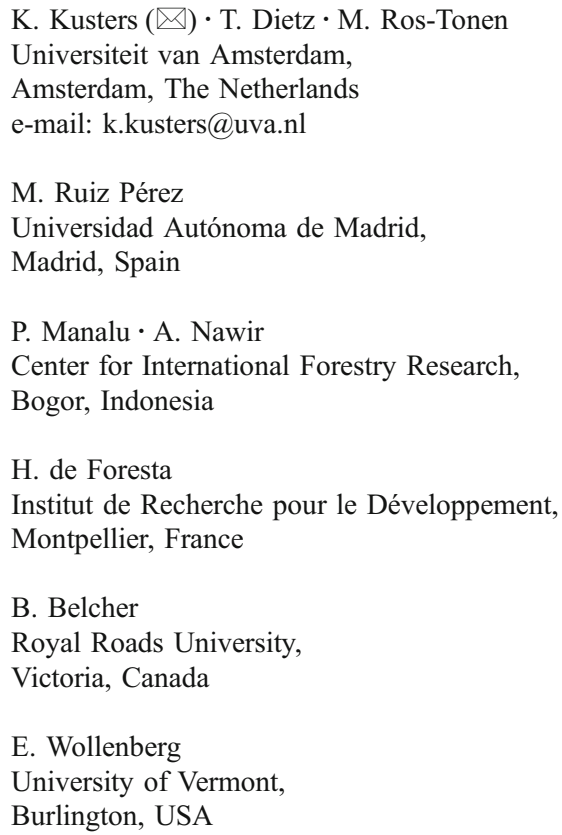

Keywords Conservation - Development - Agroforests . Land-use change $\cdot$ Sumatra $\cdot$ Indonesia

\section{Introduction}

Agroforestry practices, broadly defined as integrating trees into agriculturally productive landscapes, are increasingly receiving attention. The 2004 Nobel Prize for Wangari Maathai and her Green Belt Movement is an example. The potential contribution of agroforestry to conservation and development objectives is also increasingly receiving scientific attention (Schroth et al. 2004; McNeely and Schroth 2006) and the promotion of agroforestry was put forward as one of the means to reach the Millennium Development Goals (Garrity 2004; Garrity et al. 2006). Tree-based agricultural systems are expected to sustain long-term productivity through maintaining soil and water quality, while providing other environmental benefits, such as carbon sequestration and in some cases biological diversity (e.g., De Jong 2002). Implemented in buffer zones, they are expected to help protect remaining natural forests (Nyhus and Tilson 2004). The promotion of agroforestry practices fits well within current popular approaches towards environmental conservation that stress the need for managed landscapes in which agricultural areas provide ecosystem services (Shriar 2000; Scherr and McNeely 2003; Wiersum 2004; Sanchez 2004; Ashley et al. 2006; Vandermeer and Perfecto 2006).

Complex agroforests are anthropogenic forests that are composed of numerous individually owned and managed plots, but which appear as a forest massif (De Foresta and Michon 1997). Complex agroforest systems are intermediate on the continuum between extraction from natural 
forests and modern plantation management, both in terms of productivity as well as biodiversity (Michon and De Foresta 1997; Wiersum 1997; Van Noordwijk et al. 1997; Belcher et al. 2005). Agroforests evolve in the context of population growth and commercialisation (Henley 2005). However, they may be transitional phases that will further develop into intensively managed monocultures (Belcher et al. 2005). For example, since complex agroforests tend to have relatively low returns per hectare of land, increasing land scarcity could trigger more intensive land use, resulting in monoculture systems. This could either imply conversion to an alternative land use or transforming the agroforest system into a monospecific plantation, requiring high maintenance and using cloned varieties (cf. Gouyon et al. 1993). Some researchers found that changing cultural preferences may also induce a shift to monocultures, for example when younger generations perceive agroforest management as backwards compared to cash crop cultivation or wage labour (e.g., García Fernández 2004). Development of biodiverse tree-based systems is not helped by the dominant approaches to forestry and agriculture, which promote specialization and high input (Potter 2001; Michon et al. 2007).

While some authors stress the fragility of complex agroforest systems (Potter 2004), others stress their resilience. Michon (2005) for example writes: "Smallholder cultivated forests show great resilience vis-à-vis price fluctuations of their main commodities, an indication that these forests function with other logics than the ones related to short-term economic considerations" (pp. 140). The same author argues that intensification of agroforest management does not have to compromise diversity, as it may be based on the introduction of more species, rather than specialization. From this perspective agroforest management is promoted as an alternative rather than a transition towards modern specialized plantation management (Michon 2005).

A major obstacle to testing these hypotheses is the lack of longitudinal data (Godoy and Lubowski 1992; RuizPérez and Arnold 1996). We therefore selected a case-the Krui damar agroforest-for which household-level data were gathered in the 1990s. We then added our own survey in 2005 in order to assess its dynamics over time. The many demographic, economic and political changes that have occurred in the last decade make this case a good laboratory to assess the changing role of agroforest systems in farmers' livelihoods.

Our baseline is a household survey conducted by Wollenberg et al. in 1996 in the Krui area (see Wollenberg et al. 2001). We repeated the survey in 2005, to assess whether the Krui agroforest system is evolving toward more intensive land use. During explorative field visits in 2004 we did not find indications of a trend towards monospecific tree plantations, but we did observe damar agroforests being converted to perennial cash crops. We hypothesized that people were increasingly converting their agroforests to specialized monoculture plantations of cash crops, and expected that to be reflected in a declining importance of income from the mature damar agroforest in household income portfolios.

Our research questions were: (1) What was the difference in household income composition between 1995 and 2004? (2) Were farmers converting mature agroforests to other land uses? (3) Were farmers continuing to establish new agroforests? (4) How and why did trends differ among various parts of the Krui area? And (5) What were the implications of the observed trends for the Krui agroforests and the neighbouring national park?

In this paper we report on the main results of the comparative analysis of the two surveys and on qualitative data gathered during 2005. In the discussion section we elaborate on factors that contributed to the agroforestry systems' resilience as well as on factors that contributed to the system's fragility. We conclude by drawing more general lessons related to the resilience, threats and opportunities for diverse agroforest systems developed by local farmers that can be applied in a wider tropical context.

\section{The Damar Agroforests}

The damar agroforests of the Krui area ${ }^{1}$ in the southwestern tip of Sumatra, Indonesia, are often referred to as a showcase win-win example of a land-use system with both economic and environmental benefits (e.g., Durst et al. 2005; Sunderlin et al. 2005). The Krui area is located in Lampung Province, bounded by the Indian Ocean and Bukit Barisan Selatan (BBS) National Park. BBS National Park is the third largest National Park in Sumatra and became a UNESCO world heritage site in 2004. The park is home to three highly endangered animal species: the Sumatran tiger (Panthera tigris), the Asian elephant (Elephas maximus) and the Sumatran Rhinoceros (Dicerorhinus sumatrensis). BBS lost about $19 \%$ of its forest cover between 1972 and 2002, mainly to agricultural encroachment (Gaveau et al. 2007). A zone of man-made forest is located southwest of the National Park. The main component of this agroforest is the species Shorea javanica K. \& V., locally referred to as the damar tree. This species yields a relatively valuable resin, known as damar mata kucing, which is used in the production of incense, varnish, paint, and cosmetics. Studies conducted in the area since the mid-1980s showed that the Krui agroforests conserve soils, water systems, and a high diversity in forest plants and animals (Torquebiau 1984; Michon and De

\footnotetext{
${ }^{1}$ The area's official name is 'Pesisir', but it is commonly referred to as the 'Krui area' after the local town in the area.
} 
Table 1 The three stages of damar agroforest establishment (after Michon et al. 2000)

\begin{tabular}{lll}
\hline Year & Species planted & Main products harvested \\
\hline $0-3$ & Rainfed rice; vegetables; coffee; pepper; damar tree; other tree species & Rainfed rice; vegetables \\
& (e.g., Erythrina subumbrans; Durio zibethinus; Lansium domesticum; and Parkia speciosa) & \\
$3-15$ & None & Coffee; pepper; fruit \\
$20+$ & Replacement planting: damar and fruit trees & Damar resin, fruit \\
\hline
\end{tabular}

Between year 15 and 20 the plot is not used intensively, except for harvesting fruits and fuelwood.

Foresta 1995; Michon et al. 2000), while providing a permanent and secure flow of cash income (Budidarsono et al. 2000; Michon et al. 2000; Wollenberg et al. 2001). National and international attention to the Krui agroforests reached its pinnacle in 1998, when the Indonesian government issued a special decree that provided the Krui farmers with use rights for agroforests located on state forest lands, in order to maintain an agroforest zone buffering BBS National Park (Fay et al. 1998; Fay and De Foresta 1998; Kusters et al. 2007).

The damar agroforest is the final stage of an agricultural system that has three main stages over time (Table 1). The first productive stage after forest clearing consists of rainfed rice and vegetable cultivation. During this stage the farmer plants coffee, pepper, damar and fruit trees between the rice and vegetables. The second stage, about three years after opening the field, is that of productive coffee or pepper, or both. After about 20years coffee and pepper plants are no longer productive, but the damar and fruit trees have matured - this is the beginning of the third and final stage. Resin is tapped from the damar trees at regular intervals. Senescent damar trees are replaced through both natural regeneration and enrichment planting (Michon 1985). An important characteristic of the damar agroforest system is that its establishment is a low-cost investment, because the tree seedlings are often acquired for free, e.g., from relatives with mature agroforest, and the trees benefit from the care given to the other crops in previous stages of rainfed rice and short term perennials.

The first damar agroforests were established more than a century ago. Krui farmers started establishing damar agroforests around the 1880 s driven by a combination of decreasing abundance of naturally occurring trees and increasing resin demand from industrial varnish and paint industries (Michon et al. 2000; De Foresta and Boer 2000). With more coffee and pepper gardens evolving into mature agroforest, the agroforest area grew to about 50,000ha in 1998 (Michon et al. 2000). Though both demand and price of damar resin have been relatively stable over the years (Coppen 1995; Wollenberg et al. 2001), a study of 223 households in the Krui area in 1996 showed that $63 \%$ of the respondents would prefer to earn their income from a source other than damar, and that "...agroforest incomes may be slowly declining in importance, despite the continuing stability of the market" (Wollenberg and Nawir 2005, p. 331).

\section{Study Area}

In 1996 a socioeconomic survey was conducted in three villages in the Krui area (Wollenberg et al. 2001; Wollenberg and Nawir 2005). The villages were selected to represent the southern (Pesisir Selatan), central (Pesisir Tengah) and northern (Pesisir Utara) parts of the western coast of the Lampung province. We repeated the survey in the same villages (Fig. 1). The village of Melaya consists of a main settlement near the coast and two hamlets in the uplands. We treat these upland hamlets separately from the main village because of clear differences in land use, settlement history and ethnic background of the population. Below we summarize the key features of each research site.

- Melaya main village is located about $50 \mathrm{~km}$ north of Krui, the central town in the area. The village — situated

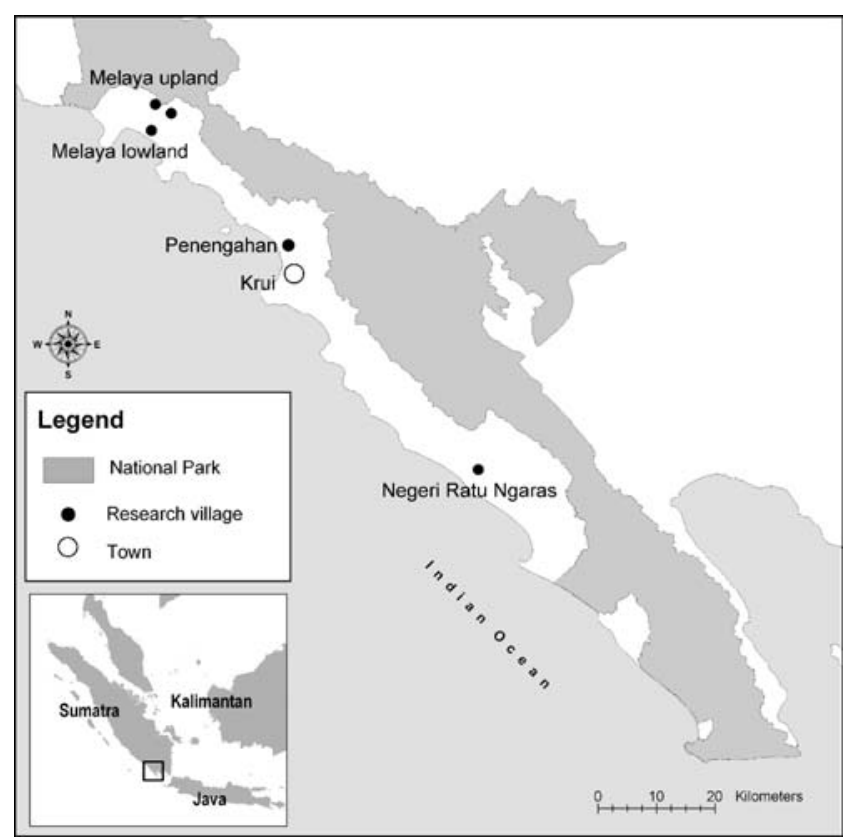

Fig. 1 Location of the research villages 
along the main road from Krui to Bengkulu province in the north — has had good road access since 1992. There are rice paddies along the coast, and mature agroforests inland.

- The two Melaya upland hamlets are located northeast of the main village, close to Bukit Barisan Selatan (BBS) National Park. Administratively the hamlets are part of the village of Melaya. Whereas the inhabitants of the other research villages are predominantly native to the Krui area, the inhabitants of the upland hamlets are mostly Javanese. The hamlets were established in the late 1970s by Javanese immigrants, with permission of the customary leader of Melaya. Of the current upland population, $70 \%$ came to the region after 1980 . Since 2000 the rate of in-migration declined. The hamlets are relatively remote, a few hours walking distance from Melaya main village along steep and muddy tracks through the agroforest. The hamlets are not accessible by motorized vehicles, except for heavy motorcycles with chained tires. Coffee and pepper cultivation is the dominant land use.

- Penengahan is the most central village, located less than $10 \mathrm{~km}$ from Krui town. There are paddy rice fields near the coast and an extended area of agroforest inland, to the boundary of BBS National Park, and beyond in some places. Of all the study villages, Penengahan has the longest history of damar cultivation and trade.

- Negeri Ratu Ngaras is located about $65 \mathrm{~km}$ south of Krui town. This part of the Krui area was opened up in 1996 with the construction of an asphalted road connecting the southern villages with Krui town. The road changed the village's access to the market considerably. Before its construction a trip from Negeri Ratu Ngaras to Krui would take several days, while now it takes only about two hours by public transportation. Negeri Ratu Ngaras has more paddy rice fields than the other research villages, because the area is much flatter. Next to paddy rice fields, the village has a large area of mature agroforest. Wollenberg et al. (2001) report that the process of establishing damar agroforests started later than in the other parts of the
Krui area. The southern research village has a relatively weak tradition of damar management compared to the central and northern villages.

Table 2 shows the increased population density in the area between 1995 and 2003, based on figures provided by the Indonesian Central Bureau of Statistics (BPS). In the eight years covered by these figures, population density rose between $20 \%$ and $40 \%$. Population density in the centre (Pesisir Tengah) is much higher than in the south (Pesisir Selatan) and north (Pesisir Utara). In the central part of the Krui area there is not much land left for agricultural expansion as the mature agroforest extends up to the steep slopes on high altitudes.

The Krui area, just like many other areas in Indonesia, experienced expansion of oil palm plantations. An Indonesian company entered the area in the mid 1990s persuading farmers to plant oil palm. Soon after that, communities, helped by a consortium of research institutions and NGOs, successfully resisted further expansion of oil palm (cf. Colchester et al. 2005; Kusters et al. 2007). Ekadinata et al. (2005) estimate that there are currently roughly 13,000ha of oil palm, all located in the south of the Krui area. There are no oil palm plantations located within the research villages.

\section{Methods}

The 1996 questionnaire by Wollenberg et al. (2001) included questions concerning household activities, income and agroforest management. Data on agricultural input and output were recorded per field and all income-related data were based on recall of the previous year. The researchers randomly sampled $20 \%$ to $25 \%$ of the population of each village, totalling 223 households. In early 2005 we returned to the same villages and repeated the survey. We randomly selected $25 \%$ of the households in each village, totalling 277 households. In addition to the survey we organized focus group interviews with adult men, adult women and adolescents in each settlement. We had in-depth interviews with nine farmers from other villages who had clearcut their agroforest. Also, between October 2004 and May 2005, we

Table 2 Population density in 1995 and 2003

\begin{tabular}{|c|c|c|c|c|c|c|}
\hline & \multicolumn{2}{|c|}{ South (Pesisir Selatan) } & \multicolumn{2}{|c|}{ Central (Pesisir Tengah) } & \multicolumn{2}{|c|}{ North (Pesisir Utara) } \\
\hline & 1995 & 2003 & 1995 & 2003 & 1995 & 2003 \\
\hline Square kilometers & 2,100 & 2,100 & 173 & 173 & 634 & 634 \\
\hline People & 45,028 & 63,146 & 36,492 & 44,932 & 19,787 & 23,664 \\
\hline People per $\mathrm{km}^{2}$ & 21 & 30 & 211 & 260 & 31 & 37 \\
\hline$\%$ change $95-03$ & & $40.2 \%$ & & $23.1 \%$ & & $19.6 \%$ \\
\hline
\end{tabular}

Source: BPS 1996 and 2004 
Table 3 Farmers' price $(\mathrm{Rp} / \mathrm{kg}$ ) for main commodities, in real 2004 terms

\begin{tabular}{lrrrr}
\hline & 1995 & 2004 & Difference & $\begin{array}{r}\text { \% change } \\
1995-2004\end{array}$ \\
\hline Damar & 4,100 & 3,800 & -300 & -7.3 \\
Coffee & 10,200 & 3,400 & $-6,800$ & -66.7 \\
Pepper & 12,600 & 9,800 & $-2,800$ & -22.2 \\
Rice & 2,400 & 2,500 & 100 & 4.2 \\
\hline
\end{tabular}

Prices in real terms are calculated with the Consumer Price Index of Lampung as produced by the Indonesian Central Bureau of Statistics. The 2004 exchange rate: US $\$ 1=$ Rp. 9,000

conducted in-depth interviews with about 100 key informants, i.e., village leaders, traders, sawmill owners, NGO staff, forest rangers, and government officials.

With the 2005 survey we gathered data for a total of 811 agricultural fields (including agroforest plots), and for each field we recorded the local name of the patch in which it is located. Each patch-locally referred to as 'atar' and varying in size from 5 to 50 ha-usually corresponds with a certain area of forest that was opened and cultivated by a group of households at around the same time. The location of each atar was later identified on detailed village maps during participatory mapping exercises. In this way we obtained the approximate location of all fields recorded in the 2005 survey. Some of the atar were identified within the boundaries of the National Park, and we used this to estimate the number of farmers with plots inside the protected area.

We compared income data for the years 1995 and 2004. The 1995 income data were adjusted using the Consumer Price Index (CPI) of Lampung Province, as calculated by the Indonesian Central Bureau for Statistics to compare with 2004 data in terms of constant purchasing power. In this article we present incomes in Indonesian rupiah using real 2004 terms. In 2004 the currency rate was Rp. 9,000 for US \$1. Incomes presented are calculated as total revenues less cash costs. Costs measured included costs of hired labour, inputs such as fertiliser for rice fields, and transportation. The costs of self-employment were not counted. Total income included the monetary value of rice produced for the household's own consumption. For the analysis we divided the different income sources in five groups:

1. Damar agroforest. The bulk of the income from the damar agroforest comes from selling damar resin, while approximately $10 \%$ comes from the selling of fruits, such as durian (Durio zibethinus Murr.), duku (Lansium domesticum Corr.), and petai (Parkia speciosa Hassk.). The income from fruits is variable over the years, as some of these species have peak yields once every few years (Bouamrane 1996). A peak yield may double the average household income for that year (De Foresta and Michon 1997). None of the surveys reported here included a fruiting peak year.

2. Rice. This category includes both rainfed rice and paddy rice. Rice is primarily produced for own consumption. Only a few households produce surplus rice that is sold in the market (in 2004, 6\% of the households occasionally sold rice). We used the farmgate price of rice (after harvesting) to calculate the monetary value of rice production.

3. Short term perennials (STP). STP are the major source of cash in addition to damar resin. Ninety-six percent of the income in this category comes from coffee and pepper.

4. Agricultural wage labour. This includes wages for assistance during rice harvests and wages for transporting and sorting damar resin.

5. Non-farm income. This category includes a wide variety of income sources, the most important ones being government employment (including teaching) and trade (including small shops).

To calculate income we used local farm-gate prices for commodities (Table 3). The main commodities in the research villages are damar resin, coffee and pepper. The real price per weight of damar resin and rice were almost similar in both years. The real prices for coffee and pepper on the other hand were much lower in 2004 compared to 1995. The real price for coffee dropped most dramatically. Data for coffee prices in the Krui area collected by Gaveau show that the real coffee price peaked in 1998, then declined up until 2002, after which it slowly started increasing again (Gaveau, personal communication) .

\section{Results}

The mean annual total household income is significantly lower in 2004 than in 1995 (Table 4). The average number of children per family did not change, but the average

Table 4 Difference in average household size and mean total income per year

\begin{tabular}{lcrc}
\hline & 1995 & 2004 & Sig. \\
\hline Average family size $^{\mathrm{a}}$ & 6.94 & 6.58 & 0.150 \\
Average household size $^{\mathrm{b}}$ & 6.17 & 5.42 & 0.020 \\
Mean income per & $11,743,160$ & $9,815,881$ & 0.033 \\
$\quad$ household (Rp.) & & & \\
Mean income per capita (Rp.) & $2,116,571$ & $2,078,190$ & 0.841 \\
\hline
\end{tabular}

${ }^{a}$ Including children that live outside the household, but did not yet start their own family

${ }^{\mathrm{b}}$ Average number of people living with the head of the household under one roof, including the head of the household 
Fig. 2 Changes in total household income composition

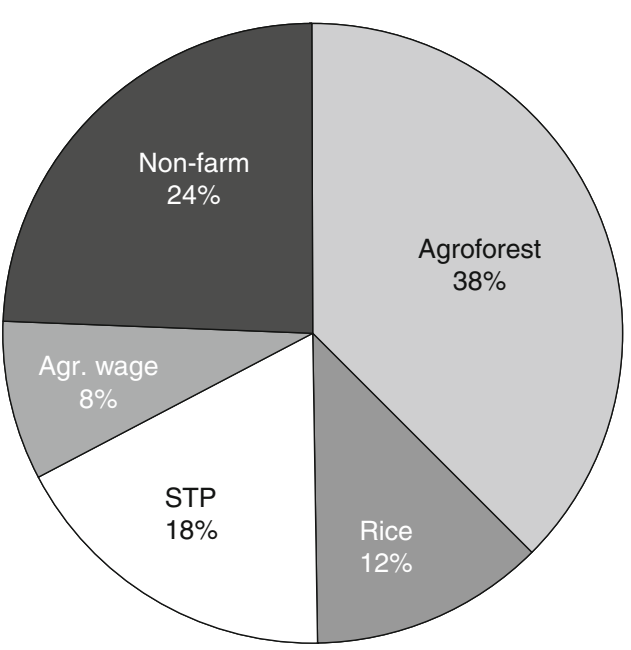

2004

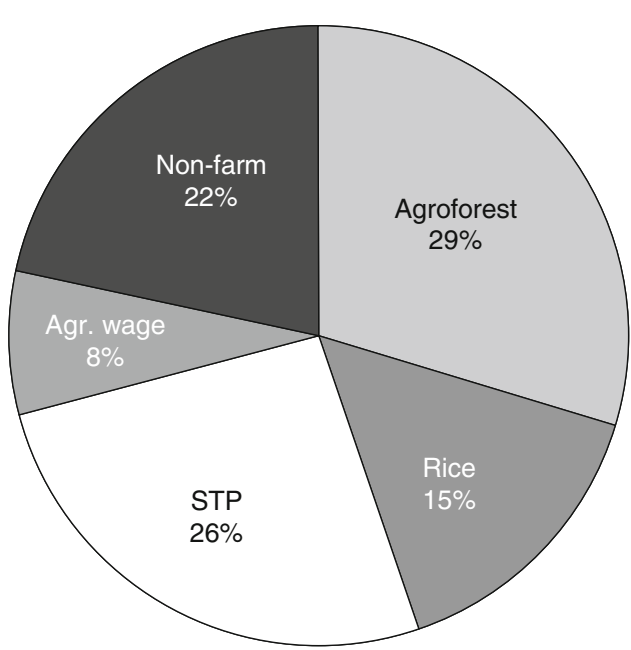

household size (the number of people living with the head of the household under one roof) decreased due to out migration of young household members to West Java. Therefore, the per capita income (calculated as income per person living with the head of the household) remained stable. The relative importance of rice, wage labour and non-farm activities was roughly similar in both years (Fig. 2), while there were larger differences in the relative importance of damar agroforest and STP. ${ }^{2}$ These two sources of income seem to have some substitution effect between them. Below we will first explore the changing income from damar agroforest, after which we will look into the increasing importance of income from STP. We also assess the extent to which households are establishing and converting damar agroforests.

\section{Decreasing Income from Mature Agroforests}

The absolute annual household income from mature agroforest decreased significantly between 1995 and 2004 (Table 5). The mean size of mature agroforest per household did not change significantly (1.03ha in 1995 and 1.06ha in 2004) and the percentage of households with mature damar agroforest also remained stable (65\% in 1995 and $64 \%$ in 2004). The small decrease in price of damar resin does not explain the decrease in mean household income from resin. Looking further into the possible reasons for the declining income we found that the resin production per hectare had decreased significantly (Table 5).

As traditional farmers' knowledge indicates that increased harvesting intensity reduces the long term productivity of a tree, we explored the relationship between resin

\footnotetext{
${ }^{2}$ The apparent stagnation in the non-farm sector is surprising as one would expect the importance of the non-farm sector to increase over time. We will address this in a separate article.
}

productivity and the average period between two harvests. We found a positive relationship (Spearman's rho correlation coefficient $=0.300 ;$ sig $=0.000$ ). Table 6 shows that harvest intervals have shortened significantly over the last decade. Reduced harvest intervals over the last decade may thus be one of the reasons for the decline in production. Though we can not prove the causality, we hypothesize that shorter harvest intervals contribute to decreasing production by increasing the likelihood of pests (e.g., Massicus scapulatus) and diseases entering the tree (Lindgren 2004). This would lead to a weakening of the structural integrity of the tree, making it more susceptible to being blown over by the wind.

The trends of shortening harvest intervals and decreasing production are apparent in all villages, but the average harvest interval is significantly shorter and the average productivity is significantly lower in the southern research village compared to the other villages (Tables 5 and 6 ). Key informants explained this by the relatively weak damar tradition in the southern village - the stronger the damar tradition in a village, the more emphasis there is on applying sufficiently long harvest intervals.

The reasons for shortening harvesting intervals were discussed in greater detail during focus group interviews with men (totalling approximately 60 participants). According to the respondents there are two reasons for shorter harvest intervals. Firstly, increased dependence on cash income, for example to pay for transport and kitchen needs, induces poor farmers to apply shorter harvest intervals to obtain immediate cash. Secondly, the longer a farmer waits to harvest, the more resin accumulates on the surface of the tree and the more likely it will get stolen. Increased occurrence of resin theft stimulates farmers to apply short harvest intervals. It confronts farmers with a 'tragedy of the commons' type of dilemma: "If I don't take it now, someone else will". 
Table 5 Changing household income from mature agroforest

\begin{tabular}{|c|c|c|c|c|c|c|c|c|c|c|c|c|}
\hline & \multicolumn{3}{|c|}{ Melaya main (north) } & \multicolumn{3}{|c|}{ Penengahan (centre) } & \multicolumn{3}{|c|}{ NR Ngaras (south) } & \multicolumn{3}{|l|}{ Total } \\
\hline & 1995 & 2004 & Sig. & 1995 & 2004 & Sig. & 1995 & 2004 & Sig. & 1995 & 2004 & Sig. \\
\hline Total income agroforest $(\times 1,000 \mathrm{Rp})$. & 5,917 & 3,062 & 0.013 & 6,198 & 4,123 & 0.009 & 5,033 & 3,902 & 0.350 & 4,411 & 2,904 & 0.001 \\
\hline Income from fruit $(\times 1,000 \mathrm{Rp})$. & 805 & 354 & 0.184 & 1,126 & 121 & 0.011 & 198 & 478 & 0.204 & 589 & 210 & 0.018 \\
\hline Income from resin $(\times 1,000 \mathrm{Rp})$. & 5,112 & 2,708 & 0.025 & 5,072 & 4,001 & 0.091 & 4,835 & 3,424 & 0.230 & 3,822 & 2,694 & 0.006 \\
\hline Resin productivity (kg/ha per year) & 1,410 & 870 & 0.052 & 1,508 & 957 & 0.000 & 795 & 675 & 0.377 & 1,362 & 857 & 0.000 \\
\hline
\end{tabular}

Upland hamlets are not included, because there are only few households with mature agroforest.

This brings us to a second reason for the decline in recorded yields, as resin theft obviously decreases the quantity of resin that can be harvested by the owner of the agroforest. It also implies that part of the produced damar (and the income thereof) remains unreported in the survey results. The adult men in each group interview agreed that: the occurrence of thievery had increased over the last decade, particularly after the years of the financial crisis; the main reasons for increasing levels of thievery are increasing population and increasing cash needs; and the main culprits are teenagers and unemployed young men. During individual in-depth interviews, some farmers shed a different light on the thievery issue. They suggested a relation with the erosion of the traditional distribution mechanism according to which the eldest son, who inherits the agroforest, is expected to provide for his extended family. In the context of the erosion of this tradition, thievery is said to occur particularly within extended families, i.e., the inheritor of the agroforest no longer feels obliged to provide support to the extended family, while the extended family still feels entitled to a share of the yield of their common ancestor's agroforest.

We also analyzed an additional data set on resin production in an experimental plot of mature agroforest established by De Foresta in the Krui area in 1993. De Foresta recorded the production of 81 trees on a monthly basis between February 1993 and February 1998. Throughout that period the resin was harvested with one-month intervals, which is the optimal harvest interval according to traditional farmers' knowledge. Thievery was no problem, because the collector lived immediately near the monitoring plot. The data show a significant progressive decline of the

Table 6 Mean harvest interval (weeks)

\begin{tabular}{llll}
\hline & 1995 & 2004 & Sig. \\
\hline Malaya main (north) & 4.52 & 2.82 & 0.000 \\
Penengahan (centre) & 5.00 & 3.58 & 0.000 \\
NR Ngaras (south) & 2.80 & 2.03 & 0.000 \\
Total & 4.35 & 2.98 & 0.000 \\
\hline
\end{tabular}

Upland hamlets are not included, because there are only few households with mature agroforest. average annual yield of resin over the years, from $1,459 \mathrm{~g}$ per tree in 1993 to $1,167 \mathrm{~g}$ per tree in 1998 . The decreasing productivity trend is common to all diameter classes, i.e., young trees are as affected as older ones. The decline could theoretically be because of a negative impact of the monthly harvest, but it could also be because of physiological factors. We suspect that the change of climatic conditions - in particular the high frequency of El Niño droughts in the last 15years $(1991,1994,1997,2003)$ may have contributed to the decline of resin production, but it would require extra research to confirm this relationship.

\section{Increasing Importance of STP}

Farmers' prices for coffee and pepper-the main STP cultivated in the Krui area-were lower in 2004 compared to 1995 (Table 3). Because of the decreasing price, the average income per hectare of STP decreased significantly from Rp. 4,567,444 to Rp. 3,318,420 (ANOVA $F=3.958$; sig $=0.048)$. The average area of STP per household did not change significantly, suggesting that there is no overall trend of expansion of the cultivated area per household. Still, the relative importance of income from STP to the total household income increased significantly (ANOVA $F=$ 10.634; sig $=0.001$ ). The rising importance of STP is related to the decreased absolute income from damar agroforests. Also, the rising importance of STP is related to a significant increase in households with STP fields (Table 7). We assume that pepper has been the dominant crop for expansion, not least because the price for pepper was exceptionally high during the years of the financial crisis (see "Discussion"). Households that were cultivating rainfed rice in 1995 had converted these fields to coffee and pepper plantations in 2004. The decreasing percentage of households with rainfed rice is illustrative of the decreasing influx of migrants and increasing levels of out-migration. ${ }^{3}$

\footnotetext{
${ }_{3}^{3}$ Overall income from rice remained stable, with decreased income from rainfed rice balanced by an increase in income from paddy rice, due to an increasing percentage of households with paddy rice in the southern research villages, made possible by the government supported construction of new paddy fields in the late 1990s.
} 
Table 7 Proportion of households with agroforest, STP, rainfed rice, and paddy rice

\begin{tabular}{|c|c|c|c|c|c|c|c|c|c|c|c|c|}
\hline & \multicolumn{3}{|c|}{ Households with rainfed rice } & \multicolumn{3}{|c|}{ Households with paddy rice } & \multicolumn{3}{|c|}{ Households with STP } & \multicolumn{3}{|c|}{$\begin{array}{l}\text { Households with mature } \\
\text { agroforest }\end{array}$} \\
\hline & $1995(\%)$ & $2004(\%)$ & Sig.* & $1995(\%)$ & $2004(\%)$ & Sig. & $1995(\%)$ & $2004(\%)$ & Sig. & $1995(\%)$ & $2004(\%)$ & Sig. \\
\hline Melaya main (north) & 13 & 0 & 0.025 & 48 & 42 & 0.644 & 29 & 67 & 0.002 & 84 & 87 & 0.751 \\
\hline Melaya upl. (north) & 21 & 11 & 0.152 & 38 & 38 & 1.000 & 81 & 97 & 0.006 & 16 & 12 & 0.802 \\
\hline Penengahan (centre) & 9 & 4 & 0.226 & 51 & 46 & 0.549 & 51 & 56 & 0.550 & 89 & 85 & 0.511 \\
\hline NR Ngaras (south) & 10 & 2 & 0.088 & 73 & 85 & 0.102 & 17 & 22 & 0.626 & 75 & 75 & 1.000 \\
\hline Total & 13 & 5 & 0.001 & 52 & 52 & 1.000 & 49 & 61 & 0.009 & 65 & 64 & 0.925 \\
\hline
\end{tabular}

*Fisher's exact test (two-sided)

There also has been a trend of 'native' farmers opening up STP fields in addition to their mature agroforest. This was particularly clear in Melaya main village, where the proportion of households cultivating STP in addition to mature agroforest grew from $19 \%$ to $58 \%$.

As mentioned above, there was no clear increase in the area of STP cultivated per household. Every year, however, new fields are opened by young farmers at the expense of fallow lands or natural forest. In the northern and southern research villages, with relatively low population densities, there are still areas of fallow lands that are used for expansion of STP. Young farmers from the central village (Penengahan) who are looking for lands to start their own farm, however, are forced to move out of the village area because all arable lands within the village area are occupied. Consequently, the Penengahan respondents have fields spread over the Krui area, while the fields from the other respondents are concentrated in their own village area
Fig. 3 Location of agricultural areas per research village

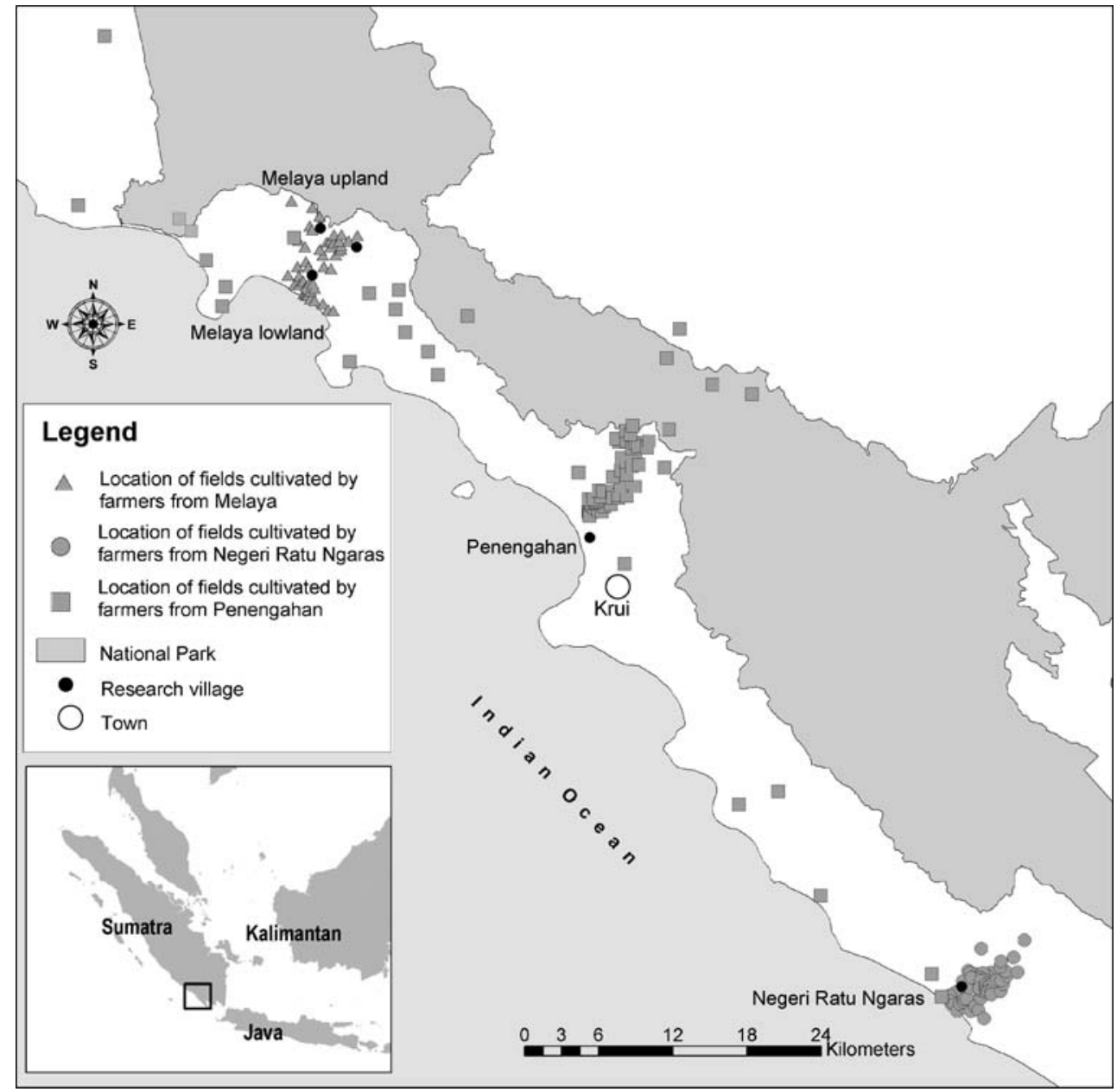


Table 8 Establishment and conversion of damar agroforest in 2004

\begin{tabular}{|c|c|c|c|c|}
\hline & \multicolumn{2}{|c|}{$\begin{array}{l}\text { STP cultivating } \\
\text { households that } \\
\text { planted young } \\
\text { damar in STP fields }\end{array}$} & \multicolumn{2}{|c|}{$\begin{array}{l}\text { Households that ever } \\
\text { converted mature } \\
\text { damar agroforest }\end{array}$} \\
\hline & Frequency & Percentage & Frequency & Percentage \\
\hline Melaya main (north) & 24 & 80 & 2 & 4 \\
\hline Melaya upl. (north) & 52 & 73 & 0 & 0 \\
\hline Penengahan (centre) & 41 & 80 & 0 & 0 \\
\hline NR Ngaras (south) & 12 & 100 & 1 & 2 \\
\hline Total & 129 & 79 & 3 & 1 \\
\hline
\end{tabular}

(Fig. 3). In 2004, 24\% of the farmers from Penengahan had a field located in one of the patches that were later identified as being located within the National Park during the participatory mapping exercises. Encroachment is, amongst other things, made possible by payments to village heads (see Kusters et al. 2007). Land scarcity in Penengahan is not new. Reportedly, Penengahan farmers have been opening lands in other parts of the Krui area since the late 1960s. Since the 1980s the focus of agricultural expansion has been in the northern part of the Krui area.

\section{Establishment and Conversion of Damar Agroforests}

Does the declining absolute and relative profitability of damar agroforest have implications for people's land-use decisions, i.e., whether or not to plant damar seedlings in STP fields, and whether or not to convert mature agroforest to other uses? Related to damar tree planting behaviour, we found that $79 \%$ of the households with STP fields in 2004 had planted damar seedlings in their fields (Table 8). Also, in the Melaya upland hamlets, where the majority of the inhabitants are of Javanese origin, $73 \%$ of the STP cultivating households had planted damar. This was unexpected, because, according to the popular perception among the Krui natives, senior forestry officials in the district capital and conservation-oriented NGOs working in the Krui area, the Javanese migrants in the uplands had a tradition of monoculture coffee cultivation and had no interest in damar agroforestry (see Niimura 2000, for an account of the possible role of outsiders promoting tree growing in these hamlets). We also addressed to what extent tree planting was influenced by tenure security, as it is often claimed that lack of tenure security impedes tree planting. Of the farmers with fields inside the National Park, $85 \%$ indicated having planted young damar in their fields. Thus, the lack of de jure tenure security does not imply that farmers refrain from establishing damar agroforests. Instead, tree planting partly functions as a way to claim or secure tenure (see Kusters et al. 2007 for a more detailed analysis of the relation between tenure security and tree planting).

With regard to the perception of youth towards agroforest practices we found that the adolescents present at the group interviews, without exception, preferred damar agroforestry over other land uses. However, agriculture (including agroforestry) was generally perceived as less attractive compared to city jobs. A possible reason for the relative attractiveness of damar agroforestry is the fact that mature agroforests allow for keeping tenure rights without demanding much work. Agroforest gardens can thus be kept as a future option while looking for work in cities.

Related to the conversion of mature agroforest, Table 8 shows that only $1 \%$ of the 277 households surveyed in 2005 indicated having ever clearcut a mature damar agroforest. Though these results may be slightly biased due to the social taboo on clearcutting damar agroforest, the responses by farmers seem to indicate that mature agroforests are for the moment generally being maintained in the research villages included in our survey. Asking the 166 farmers with mature agroforest in 2005 for their plans in the coming ten years, $90 \%$ said they intended to maintain their agroforests. We also asked all respondents in the 2005 survey about their predictions regarding the overall agroforest area in their village. Here a more mixed picture appeared, with $34 \%$ of the 277 respondents predicting the agroforest area would decrease in the coming ten years as the result of clearcutting. The difference may be indicative of the social taboo associated with damar cutting. Farmers seem reluctant to acknowledge their own conversion as a possibility in the future, though they acknowledge that others might do so.

According to our survey results farmers in the research villages are not converting mature damar agroforest to other land uses. We did, however, observe several clearcut agroforests in the southern part of the Krui area. These cleared plots belonged to farmers from southern villages not falling within our survey. We interviewed nine farmers who had clearcut their agroforests and replaced them with STP. As reason for conversion they indicated: (1) declining production of resin; and (2) rising price and demand for damar timber. The farmers used the money to purchase expensive consumer goods, such as motorcycles, or to invest in other productive activities, such as the purchase of a cart to transport fruit and timber.

In the southern Krui area, village leaders, damar traders, as well as timber traders indicated their expectation that conversion rates would increase in the near future. Several of these key informants referred to the emerging trend as the "tsunami of damar logging". At the same time, these respondents stressed that farmers are not likely to abandon the practice of planting damar tree seedlings in STP gardens. Indeed, we found that seven out of the nine 
farmers who had converted their mature agroforest had already planted damar and fruit tree seedlings in their newly established STP gardens. In other words, they are starting the process of damar agroforest establishment.

It is no coincidence that the conversion of mature damar agroforest was observed in the south. As was mentioned earlier, the mean resin production per hectare is significantly lower in the southern research village, which seems related to the relatively weak damar tradition. Furthermore, in the villages with a relatively long history of damar cultivation and a strong damar-related tradition-the central and northern research sites-unwritten traditional rules prohibit the cutting of productive damar trees for commercial purposes. In these villages there is a strong notion of heritage. There is not only a social taboo on cutting the trees planted by the forefathers but also a social obligation to maintain the agroforest for future generations. The lack of such a traditional conservation ethic in the south means that there is less social pressure to maintain the mature agroforest and no traditional taboo on clearcutting mature agroforest. There are more factors that help explain the difference between the south and the rest of the area. First, it is difficult for southern farmers to get financial credit from wealthy traders from central Krui due to the lack of social capital between the south and the centre (related to the fact the south was until recently isolated from the rest of the Krui area). For purchasing expensive goods the southern farmers thus have little choice but to sell their damar timber. Second, in the more hilly central and northern parts of the Krui area there are fewer wet rice fields compared to the south, and the income from damar resin is therefore more important for food security, i.e., to purchase rice (cf. Wollenberg et al. 2001). When an income-earning activity plays an important role in providing food security, people are more likely to maintain that activity. Also, the relief of the terrain in the north makes it more difficult and expensive to extract timber.

\section{Discussion}

In mid-1997 Indonesia was hit by a financial crisis, and the rupiah decreased in value against the US dollar from $\mathrm{Rp}$. 2,400 in July 1997 to an average of Rp. 8,300 between September 1997 and September 1999. The depreciation of the rupiah meant a sudden increase in prices for export commodities. The net results for export commodity producing farmers, however, varied. For some export commodities, like rubber, the price did not rise as much as the cost of living, and there was no increase in purchasing power. Coffee and pepper producers were more fortunate. The price for pepper in particular rose spectacularly. During the years of the financial crisis, the high prices boosted the local economy in the Krui area. In line with Sunderlin et al. (2001), we assume that most of the expansion of short-term perennials (STP) in the Krui area that we recorded between 1995 and 2004 took place as a reaction to the high prices - possibly facilitated by the relaxation of encroachment control after the fall of Suharto. Small farmers decided to clear land for coffee and pepper cultivation, following the example of fellow villagers who were suddenly earning very high incomes. The sudden increase in purchasing power and consequent increased consumption possibilities, in combination with the start of political reforms, fueled future expectations of the Krui communities. This is likely to have been particularly so in the southern research village, that had only recently been 'opened up' to the outside world. In the years following the crisis, the normalizing exchange rate and decreasing world prices caused incomes to drop again. ${ }^{4}$ The cash income per hectare of STP decreased, but (consumption) aspirations may not have decreased. We believe that these dynamics have reinforced trends that are at odds with traditional norms and rules, namely cutting damar trees for timber and damar resin thievery. ${ }^{5}$

The survey results showed that, overall, damar agroforests were maintained in the research villages between 1995 and 2004. The most likely land-use alternative for damar agroforest is conversion to STP such as coffee, pepper, and more recently introduced STP such as oranges. ${ }^{6}$ Our survey results showed that mean net returns (excluding costs of self-employment) per hectare of mature agroforests were significantly higher than those of STP fields in 1995 (Rp. 5,523,139 and Rp. 4,567,444 respectively) and that they were more or less equal in 2004 (Rp. $3,273,899$ and Rp. 3,318,420 respectively). Budidarsono et al. (2000) found that labour requirements for the productive stage of the coffee and pepper gardens are much higher than that of mature agroforest management. This suggests that, even though the returns to land of damar agroforests are decreasing, they are still economically competitive with STP cultivation in terms of returns to labour. All the more so, considering there were no peak fruit harvests recorded in our datasets (see Bouamrane 1996). It is thus not surprising that farmers are still establishing new agroforests, by planting trees in their STP gardens. Another

\footnotetext{
${ }^{4}$ Increased local supply of STP may also have had a local price effect.

${ }^{5}$ Wollenberg et al (2001) indicated that theft was a problem in 1995 as well, and that it was a reason to harvest more regularly. In the group interviews conducted in 2005, however, it was emphasized that thievery increased immediately after the financial crisis, associated with increased unemployment of young men.

${ }^{6}$ Depending on the strategy of the oil palm company that is present in the Krui area, oil palm may (re-) emerge as a tempting land-use alternative to farmers in the Krui area in the future.
} 
advantage of mature agroforest management over STP cultivation is that damar income is spread over the year as opposed to the seasonal and risky income from STP. There are also non-financial factors that help explain the damar agroforest's maintenance. In the villages with a relatively long history of damar cultivation farmers are more reluctant to convert. These findings converge with the findings of Wollenberg et al. (2001) who found that considerations of cash income alone did not suffice to explain farmers' agroforest management behaviour.

Even though damar production is characterized by a relatively stable market and price, there are indications that farmers are increasingly tempted to cash in on damar timber, being pushed by decreasing resin productivity, while being pulled by the large sums of money offered by traders for the timber of an agroforest plot. There may be a certain threshold of profitability of the damar agroforest, under which farmers are likely to prefer to sell their timber. Considering prices and demand for damar timber are on the rise, while resin productivity is declining all over the research area, conversion may not remain restricted to the southern Krui area. If current trends continue, it is questionable whether the traditional agroforest conservation ethic in the central and northern research villages will be stronger than the temptation of immediate cash. Moreover, the long-term profitability of harvesting timber and cultivating short term perennials could turn out to be higher than maintaining the mature agroforest and there are indications that an increasing number of farmers is starting to think along these lines. However, regardless of the likelihood of increased levels of conversion of mature agroforest in the area, there are no indications that people are abandoning tree-planting practices. Whether or not farmers will continue tree-planting practices in the future will depend on (1) the emergence of alternative land-use options that can tempt farmers to abandon agroforestry practices and switch to monocultures (e.g., oil palm); and (2) the extent to which the profitability of mature damar agroforests can be maintained or increased.

Increasing the profitability of the damar agroforest could be an incentive for farmers to refrain from clearcutting mature agroforests. This would have beneficial effects for the environment, as the zone with mature agroforest has important on-site and off-site environmental values. Considering the rising price and demand for damar timber, selective timber extraction may offer an opportunity without endangering the overall system (e.g., De Foresta and Michon 1993; Petit and De Foresta 1997). The damar farmers of the Krui area have a long history of tree management, and their agroforests provide regular cash income from a non-timber product. These characteristics offer opportunities for selective logging of timber, but this may require extra incentives to stimulate long-term strate- gies, instead of short-term profit maximizing. Indeed, the risk is that cutting for commercial timber, once started, may be difficult to stop. Increasing the returns to land of the mature agroforest could (theoretically) also be achieved through: the introduction of commercial shade-tolerant species; lifting the market price of damar resin (for example through price arrangements and developing green niche markets); and payments for the damar agroforest's environmental services. Payments for Environmental Services are increasingly receiving attention as a mechanism to reward farmers who ensure the maintenance of services that are important for the society at large. Partnerships between local farmers, businesses, national NGOs and international donors could be instrumental in developing such mechanisms (Ros-Tonen 2007). Our findings suggest, however, that any strategy aimed at improving the profitability of damar agroforests would need to be combined with efforts to prevent thievery so as to enable farmers to apply longer harvest intervals. Longer intervals are expected to help to maintain the agroforest's productivity. And, more concretely, longer intervals improve the resin's quality, resulting in higher prices per kilogram of resin. This is supported by recent research by Van Lakerveld (2007) and Meissner (2007) who stress that the most effective way to increase farmers' incomes would be to focus on the production of higher quality damar.

Higher returns per unit of agroforest may help to maintain the agroforest. Maintenance of the mature agroforest does, however, not prevent agricultural expansion at the expense of natural forest. Young farmers who do not inherit their father's agroforest are opening new fieldswhich will evolve into mature damar gardens over time. In essence, the situation encountered in 2004 is not much different from the situation described by Mary and Michon (1987), who concluded that agroforests were not preventing farmers from driving back the natural forest. Such agricultural expansion in the Krui area cannot be seen out of the context of the traditional inheritance system, according to which the bulk of the property goes to the eldest son in order to avoid land division, and younger sons need to find new lands themselves (Mary and Michon 1987). Some authors suggest that in a situation of land scarcity, increasing the returns to land would decrease pressure on remaining areas of natural forest (cf. Mellor 2002). But, under the current inheritance system and the demographic pressure in the research area, increasing the returns to land is not likely to decrease pressure on remaining forest. Indeed, it could even increase when the higher level of income is used to invest in agricultural expansion.

Without enforced protection, agricultural expansion at the expense of the BBS National Park is likely to continue, and new agricultural fields that are opened within the boundaries of the National Park are likely to evolve into 
agroforests over time. This situation confronts the government with a complicated choice, i.e., whether to allow expansion of agriculture and stimulate the development of agroforests at the expense of one of the last few remnants of natural rain forest in Sumatra, or to enforce protection of the National Park, thereby restricting agricultural expansion and limiting the livelihood options of local communities. The latter is likely to result in park-community conflicts if not combined with significant efforts to support local incomes.

\section{Conclusions}

Comparing household survey data of 1995 and 2004 we found that the income from mature agroforests remained the most important source of income. Farmers did not convert mature damar agroforest at any significant scale, and continued to introduce tree seedlings in their STP gardens. There are indications that the near future will bring increased levels of conversion of the agroforests, but we found no indications that increased levels of conversion would mean a fast transition to specialized plantation management.

The choice of whether or not to convert mature agroforest is influenced by financial push and pull factors and by the strength of traditions that favour agroforest conservation. The most important factor that may drive conversion is the financial opportunity provided by the timber industry. There are two main counterbalancing factors: First, there is the financial attractiveness of damar agroforest management compared to other land uses - not only in terms of risk avoidance, and income spreading over the year, but also in terms of returns to land and returns to labour. Second, there are the existing (but weakening) customary rules that favour agroforest conservation.

It is increasingly argued that agroforests have potential to reconcile rural development and biodiversity conservation. On the basis of our study we conclude there is scope for agroforest systems to provide an alternative rather than a transition to specialized plantation management. However, as many rural communities are confronted with increasing dependency on cash income for daily needs, the future of complex agroforest systems will depend mainly on their financial competitiveness with land-use alternatives. Also, the relation between agroforest promotion and biodiversity conservation is not always straightforward. Agroforest systems may provide important environmental services, but their development does not prevent agricultural pressure on protected areas in situations of relative land scarcity - in the Krui case, developing new agroforests now often means destroying protected forest. Conservation practitioners thus may need to find a compromise between enforced protection, allowing agricultural expansion while promoting agroforest development, and supporting other incomegenerating activities of farmers.

The Krui case presents several lessons. It shows that commercialization of timber may emerge as an opportunity for agroforest farmers, but may at the same time be the main threat to maintenance of standing agroforests. It also provides an example of how the productivity of agroforest systems may be influenced by both physiological factors and management practices. The latter may in their turn be rooted in sociocultural changes such as the erosion of traditions. The Krui case underlines that interventions to support complex agroforest systems should start with the identification of local problems and opportunities. One of the key problems in the Krui area is highly context specific, namely thievery and its impact on the length of harvest intervals. Before considering the possibilities of popular blueprint concepts like 'green niche markets' and 'Payments for Environmental Services', such local problems would need to be addressed. Another lesson would be that historical events, like the Asian financial crisis, can have a long-term effect by shifting behaviour patterns. Lastly, the perception of a land-use system depends on whether one looks at the system at one point in time, or whether one places the system in its dynamic context. From a broader perspective clearcutting activities may be part of a larger cycle - cashing in on trees planted by previous generations, while planting trees for future generations.

Acknowledgement The study was financially supported by CIFOR and is part of $\mathrm{PhD}$ research funded by the Universiteit van Amsterdam. We thank two anonymous reviewers for their useful comments. We also thank Patrice Levang for comments on an earlier version of the paper and the NGOs LATIN, WALHI, LPSd Beguai Jejama, YBWS and PMPRD for assisting the fieldwork.

Open Access This article is distributed under the terms of the Creative Commons Attribution Noncommercial License which permits any noncommercial use, distribution, and reproduction in any medium, provided the original author(s) and source are credited.

\section{References}

Ashley, R., Russell, D., and Swallow, B. (2006). The Policy Terrain in Protected Area Landscapes: Challenges for Agroforestry in Integrated Landscape Conservation. Biodiversity and Conservation 15: 663-689.

Belcher, B., Michon, G., Angelsen, A., Ruiz-Perez, M., and Asbjornsen, H. (2005). The Socioeconomic Conditions Determining the Development, Persistence, and Decline of Forest Garden Systems. Economic Botany 59: 3245-253.

Bouamrane, M. (1996). A Season of Gold: Putting a Value on Harvests from Indonesian Agroforests. Agroforestry Today 8: 18-10.

Budidarsono, S., Arifatmi, B., De Foresta, H., and Tomich, T. P. (2000). Damar Agroforest Establishment and Sources of Livelihood. A Profitability Assessment of the Damar Agroforest System in Krui, Lampung, Sumatra, Indonesia, Southeast Asia policy Research Working Paper, no. 17, ICRAF, Bogor. 
Colchester, M., Ekadinata, A., Fay, C., Pasya, G., Situmorang, L., Sirait, M. T., Van Noordwijk, M., Cahyaningsih, N., Budidarsono, S., Suyanto, S., Kusters, K., Manalu, P., and Gaveau, D. (2005). Facilitating agroforestry development through land and tree tenure reforms in Indonesia, ICRAF Southeast Asia Working Paper no. 2005 2, ICRAF, Bogor.

Coppen, J. J. W. (1995). Gums, resins and latexes of plant origin, Non-Wood Forest Products 6. Food and Agriculture Organization of the United Nations (FAO), Rome.

De Foresta, H., and Michon, G. (1993). Creation and management of rural agroforests in Indonesia: potential applications in Africa. In Hladik, C. M., Pagezy, H., Linares, O. F., Hladik, A., Semple, A., and Hadley, M. (eds.), Tropical Forests, People and Food: Biocultural Interactions and Applications to Development. UNESCO and the Parthenon Publishing Group, Paris, pp. 709-724.

De Foresta, H., and Michon, G. (1997). The Agroforest Alternative to Imperata Grasslands: When Smallholder Agriculture and Forestry Reach Sustainability. Agroforestry Systems 36: 1-3105-120.

De Foresta, H., and Boer, E. (2000). Shorea javanica Koord. \& Valeton. In Boer, E., and Ella, A. B. (eds.), Plant Resources of South-East Asia. No. 18: Plants Producing Exudates. Backhuys Publishers, Leyden, pp. 105-109.

De Jong, W. (2002). Forest Products and Local Forest Management in West Kalimantan, Indonesia: Implications for Conservation and Development, Tropenbos-Kalimantan Series 6. Tropenbos International, Wageningen.

Durst, P. B., Brown, C., Dacio, H. D., and Ishikawa, M. (eds.) (2005). In Search of Excellence. Exemplary Forest Management in Asia and the Pacific, Regional Community Forestry Training Center for Asia and the Pacific, Food and Agriculture Organization of the United Nations Regional Office for Asia and the Pacific (FAO), Bangkok.

Ekadinata, A., Kusters, K., Widayati, A., Gaveau, D., and Aslan (2005). Landcover dynamics in West Lampung, Sumatra, Indonesia, Technical report submitted for ICRAF Internal Workshop: Impact Study of ICRAF Land and Tree Tenure Programme, Bogor, 1-2 August 2005, ICRAF, SEA Regional Office. http://www.worldagroforestry.org/sea/Publications/ searchpub.asp?publishid $=1283$.

Fay, C. and De Foresta, H. (1998). Progress Towards Increasing the Role Local People Play in Forest Lands Management in Indonesia. Paper prepared for the Workshop on Participatory Natural Resource Management in Developing Countries, Mansfield College, Oxford, 6-7 April 1998.

Fay, C., De Foresta, H., Sirait, M., and Tomich, T. P. (1998). A policy breakthrough for Indonesian farmers in the Krui damar agroforests. Agroforestry Today 10: 225-26.

García Fernández, C. (2004). Benzoin, a resin produced by Styrax trees in North Sumatra Province, Indonesia. In Kusters, K., and Belcher, B. (eds.), Forest Products, Livelihoods and Conservation. Case Studies of Non-Timber forest Product Systems. Volume 1-Asia. Center for International Forestry Research (CIFOR), Bogor.

Garrity, D. (2004). Agroforestry and the Achievement of the Millennium Development Goals. Agroforestry Systems 61: 5-17.

Garrity, D., Okono, A., Grayson, M., and Parrott, S. (eds.) (2006). World Agroforestry into the Future, World Agroforesty Centre, Nairobi.

Gaveau, D. L. A., Wandono, H., and Setiabudi, F. (2007). Three Decades of Deforestation in Southwest Sumatra: Have Protected Areas Halted Forest Loss and Logging, and Promoted Regrowth? Biological Conservation 134: 2007495-504.

Godoy, R., and Lubowski, R. (1992). Guidelines for the Economic Valuation of Non-timber Tropical Forest Products. Current Anthropology 33: 4423-433.

Gouyon, A., De Foresta, H., and Levang, P. (1993). Does "Jungle Rubber" Deserve its Name? An Analysis of Rubber Agroforestry Systems in Southeast Sumatra. Agroforestry Systems 22: 181-206.
Henley, D. (2005). Agrarian Change and Diversity in the Light Of Brookfield, Boserup and Malthus: Historical Illustrations from Sulawesi, Indonesia. Asia Pacific Viewpoint 46: 2153-172.

Kusters, K., De Foresta, H., Ekadinata, A., and van Noordwijk, M. (2007). Towards Solutions for State vs. Local Community Conflicts Over Forestland: The Impact of Formal Recognition of User Rights in Krui, Sumatra, Indonesia. Human Ecology 35: $4427-438$

Lindgren, M. (2004). Management of Damar Trees Shorea Javanica to Prevent Damage Caused by Longhorn Beetles (Coleoptera; Cerambycidae) in Sumatra. Swedish University of Agricultural Sciences, Uppsala.

Mary, F., and Michon, G. (1987). When Agroforests Drive Back Natural Forests: A Socio-Economic Analysis of a Rice-Agroforest System in Sumatra. Agroforestry Systems 5: 27-55.

McNeely, J. A., and Schroth, G. (2006). Agroforestry and Biodiversity Conservation-Traditional Practices, Present Dynamics, and Lessons for the Future. Biodiversity and Conservation 15: 549554.

Meissner, L. (2007). The Damar Trade Chain-Relations of Trust and Power, MSc thesis, University of Amsterdam.

Mellor, J. W. (2002). Poverty Reduction and Biodiversity Conservation: The Complex Role for Intensifying Agriculture. WWF Macroeconomics Program Office, Washington, DC.

Michon, G. (1985). De l'homme de la forêt au paysan de l'arbre: agroforesteries indonésiennes, $\mathrm{PhD}$ thesis, Université des Sciences et Techniques du Languedoc (USTL), Montpellier.

Michon, G. (2005). Domesticating forests. How farmer manage forest resources. Centre for International Forestry Research (CIFOR) and The World Agroforestry Centre (ICRAF), Bogor.

Michon, G., and De Foresta, H. (1995). The Indonesian agro-forest model: forest resource management and biodiversity conservation. In Halladay, P., and Gilmour, D. A. (eds.), Conserving Biodiversity Outside Protected Areas: The Role of Traditional Agro-Ecosystems. IUCN Forest Conservation Programme, Gland, pp. 90-106.

Michon, G., and De Foresta, H. (1997). Agroforests: Pre-Domestication of Forest Trees or True Domestication of Forest Ecosystems? Netherlands Journal of Agricultural Science 45: 451-462.

Michon, G., De Foresta, H., Kusworo, A., and Levang, P. (2000). The damar agroforests of Krui: justice for forest farmers. In Zerner, C. (ed.), People, Plants and Justice. Columbia University Press, New York, pp. 159-203.

Michon, G., De Foresta, H., Levang, P., and Verdeaux, F. (2007). Domestic Forests: A New Paradigm for Integrating Local Communities' Forestry Into Tropical Forest Science. Ecology and Society 12(2): 1. http://www.ecologyandsociety.org/voll2/ iss $2 /$ art1/

Niimura, Y. (2000). Knowledge, Social Dynamics and Damar Agroforests: the Role of Outsiders in Promoting Sustainable Local Resource management in Pesisir Krui, Indonesia. MA thesis, Wye College, University of London, London.

Nyhus, P., and Tilson, R. (2004). Agroforestry, elephants, and tigers: balancing conservation theory and practice in human-dominated landscapes of Southeast Asia. Agriculture, Ecosystems and Environment 104: 200487-97.

Petit, S., and De Foresta, H. (1997). Precious Woods from the Agroforests of Sumatra-Where Timber Provides a Solid Source of Income. Agroforestry Today 9: 418-20.

Potter, L. (2001). Agricultural Intensification in Indonesia: Outside Pressures and Indigenous Strategies. Asia Pacific Viewpoint 42: 2/3205-324.

Potter, L. (2004). Can Indonesia's Complex Agroforests Survive Globalisation and Decentralisation? A study in Sanggau district, West Kalimantan. Paper presented to the 15th Biennial Conference of the Asian Studies Association of Australia in Canberra 29 
June-2 July 2004. http://coombs.anu.edu.au/SpecialProj/ASAA/ biennial-conference/2004/Potter-L-ASAA2004.pdf.

Ros-Tonen, M. A. F. (ed.) in collaboration with Van den Hombergh, H., and Zoomers, A. (2007). Partnerships in Sustainable Forest Resource Management: Learning from Latin America, Brill, Leiden.

Ruiz Pérez, M., and Arnold, J. E. M. (1996). Current Issues in NonTimber Forest Products Research. Center for International Forestry Research (CIFOR), Bogor.

Sanchez, P. A. (2004). Delivering on the Promise of Agroforestry. Environment, Development and Sustainability 1: 3-4275-284.

Scherr, S. J., and McNeely, J. A. (2003). Ecoagriculture Strategies for Poverty Reduction and Biodiversity Conservation. Paper presented at the international workshop on "Reconciling Rural Poverty Reduction and Resource Conservation: Identifying Relationships and Remedies", May 2-3, 2003, Cornell University, Ithaca, NY.

Schroth, G., Da Fonseca, G. A. B., Harvey, C. A., Gascon, C., Vasconcelos, H. L., and Izac, A-M. N. (eds.). (2004). Agroforestry and Biodiversity Conservation in Tropical Landscapes, Island Press, Washington DC.

Shriar, A. J. (2000). Agricultural Intensity and Its Measurement in Frontier Regions. Agroforestry Systems 49: 301-318.

Sunderlin, W. D., Angelsen, A., Resosudarmo, D. P., Dermawan, A., and Rianto, E. (2001). Economic Crisis, Small Farmer WellBeing, and Forest Cover Change in Indonesia. World Development 29: 5767-782.

Sunderlin, W. D., Angelsen, A., Belcher, B., Burgers, P., Nasi, R., Santoso, L., and Wunder, S. (2005). Livelihoods, Forests, and
Conservation in Developing Countries: an Overview. World Development 33: 91383-1402

Torquebiau, E. (1984). Man-made Dipterocarp Forest in Sumatra. Agroforestry Systems 2: 103-127.

Vandermeer, J., and Perfecto, I. (2006). The Agricultural Matrix and a Future Paradigm for Conservation. Conservation Biology 21: 1274-277.

Van Lakerveld, A. (2007). Price Determination and Upgrading Within the Damar Trade Chain. MSc thesis, University of Amsterdam.

Van Noordwijk, M., Tomich, T. P., De Foresta, H., and Michon, G. (1997). To Segregate - Or to Integrate? The Question of Balance Between Production and Biodiversity Conservation in Complex Agroforestry Systems. Agroforestry Today 9: 16-9.

Wiersum, K. F. (1997). Indigenous Exploitation and Management of Tropical Forest Resources: An Evolutionary Continuum in Forest-People Interactions. Agriculture, Ecosystems and Environment 63: 1-16.

Wiersum, K. F. (2004). Forest Gardens as an 'Intermediate' Land-Use System in the Nature - Culture Continuum: Characteristics And Future Potential. Agroforestry Systems 61: 123-134.

Wollenberg, E., and Nawir, A. (2005). Turning Straw Into Gold: Specialization among Damar Agroforest Farmers in Pesisir, Sumatra. Forests, Trees and Livelihoods 15: 4317-336.

Wollenberg, E., Nawir, A., Uluk, A., and Pramono, H. (2001). Income is Not Enough: The Effect of Economic Incentives on Forest Product Conservation - A comparison of Forest Communities Dependent on the Agroforests of Krui, Sumatra and Natural Dipterocarp Forests of Kayan Mentarang, East Kalimantan. Center for International Forestry Research (CIFOR), Bogor. 